\title{
The lavender scare: the cold war persecution of gays and lesbians in the federal government
}

David K. Johnson, University of Chicago Press, Chicago, 2004, ISBN 0-2264-0190-1 £13.00 (Pbk) 312p; ISBN 0-2264-0481-1 £21.00 (Hbk) 280p

Like all civil service employees working during the Eisenhower administration, Madeleine Tress - a 24-year-old business economist at the Department of Commerce in Washington, $D C$ - was required to pass a security investigation as a condition for employment. At her position for only a few months, on that April day in 1958, Madeline was led into a room by two male interrogators who began the 'interview' by asking her a few mundane questions regarding her name, where she lived, and her date of birth. 'Miss Tress', one of the interrogators then retorted, 'the Commission has information that you are an admitted homosexual. What comment do you wish to make regarding this matter?' (quoted in Johnson, 2004: 148). Shocked, Madeleine froze and refused to answer the question. The men disclosed that they had reliable information that she had been seen frequenting a gay bar, the Redskins Lounge, and they named a number of her lesbian and gay male friends. One of the men then sneered, 'How do you like having sex with women? You've never had it good until you've had it from a man.' Tormented into silence, following the interrogation, she refused to sign a document admitting her alleged 'crime'. The next day, Madeleine Tress handed in her official resignation. By the late 1950s, literally thousands of women and men working in Washington, DC experienced similar inquisitorial grillings conducted under the guise of 'national security'.

There are moments in history when conditions come together to signal a seismic shift in the social and political geography. Three critical moments sparked an era of fear, suspicion, and repression leading to the interrogation of Madeleine Tress. The first occurred during the Truman administration in June 1947 when the US Senate Appropriations Committee warned Secretary of State Marshall that a concerted effort was being carried out 'to protect Communist personnel in high places' (p. 21), and that this subversive project involved 'the extensive employment in highly classified positions of admitted homosexuals who are historically known to be security risks' (p. 21). In their attempts to counter these alleged security lapses, the Committee attached the McCarran rider to an appropriations bill giving the Secretary of State authority to dismiss any employee at his 'absolute discretion' to promote public security. A second critical moment occurred three years later, in February 1950, when a relatively young and brash US Republican Senator from Wisconsin, Joseph McCarthy, provocatively claimed in a speech in Wheeling, West Virginia that 205 'card-carrying Communists' worked for the US State Department. In part as a response to McCarthy's allegations, the third moment transpired when Deputy Undersecretary 
of State, John Peurifoy, testified at a Senate appropriations committee meeting on 28th February 1950 denying, on the one hand, that his Department hired Communists, but, on the other hand, disclosing that a number of persons had been fired for being 'security risks', including 91 homosexuals. These disclosures set off a firestorm. Within one month, Republicans in the Congress ordered investigations looking into the extent of the 'homosexual problem' and the 'infiltration of sexual perverts' in government.

Drawing on a variety of primary sources - many only declassified and opened to the public in 2000 - plus oral histories of people who lived and worked in Washington, $D C$ at the time, and newspaper accounts, magazines, novels, and films, David K. Johnson reconstructs an era of persecution and purges of lesbian, gay, bisexual, and transgendered people, as well as their heterosexual allies, in what the author has dubbed the 'Lavender Scare' during the height of the Cold War.

In the mind of many officials and in the public imagination, homosexuals and Communists in government posed similar threats. According to Johnson:

Both groups were perceived as alien subcultures that recruited the psychologically maladjusted to join in immoral behavior that threatened the nation's survival. Many claimed the two groups were working together.

It is important to note that the Soviet government itself criminalized homosexuality under Joseph Stalin and blamed homosexuality on the West as a product of 'bourgeois decadence'. The US countered by blaming homosexuality on a Soviet Communist international 'godless conspiracy'. The so-called 'Red Scare' was said to have been saturated with lavender: the colour associated with homosexuality at the time. Some US government officials connected the Comintern (an international Communist organization) with what they termed the 'Homintern', which they saw as an international homosexual conspiracy linked with Communists. As Johnson makes clear, although gay and lesbian US citizens were never blackmailed into divulging classified state information and that connections between homosexuality and 'security risk' were groundless, mere allegations of homosexuality triggered congressional hearings, Presidential Executive Orders (for example, Eisenhower's Order 10450, which extended and enlarged the Harry Truman loyalty/security programme to exclude explicitly those who engage in 'sexual perversion' from obtaining government jobs), as well as executive agency security briefings.

A determination of the exact numbers of women and men harmed by the anti-homosexual inquisition cannot be known since detailed records were not kept and many individuals simply resigned before they were interrogated. Johnson estimates, however, that approximately 5,000 federal agency employees lost their jobs on suspicions of homosexuality during the 1950s through early 1960 s. 
Although there are some glaring omissions in Johnson's book, including substantive discussions of Roy Cohn (a top aid to Joseph McCarthy) and FBI chief J. Edgar Hoover's involvement in the Lavender Scare, plus overarching connections between the anti-Communist campaigns with pervasive antiSemitism in the United States, Johnson makes a valuable contribution to our understanding of an often forgotten and overlooked facet of US history, and to the sociopolitical mechanics of scapegoating, persecution, and marginalization.

doi:10.1057/palgrave.fr. 9400297

Warren J. Blumenfeld

\section{Locked in the family cell: gender, sexuality and political agency in Irish national discourse}

Kathryn A. Conrad, University of Wisconsin Press, Madison, WI, 2004, ISBN 0-299-19650-X£31.50 (Hbk) 196p

The notion of the 'family cell', which is the subject matter of this book, is taken from Foucault's The History of Sexuality which identified this as the form, in 18th century Europe, that 'made it possible for the main elements of the deployment of sexuality (the feminine body, infantile precocity, the regulation of births, and to a lesser extent no doubt, the specification of the perverted) to develop along its two primary dimensions: the husband-wife axis and the parents-children axis' (p. 4). This book, while acknowledging the significance of the family cell to all nations, associates its particular significance in the Irish context with the patriarchal system of familial relations that emanated from the forces of Christianity, but also from a British colonialism that identified the answer to 'the Irish problem' as lying in the trope of marriage in which the maiden Hibernia would be rescued and restored to order by a patriarchal John Bull. The centrality of the heteronormative family is echoed in Irish nationalist discourse, which located the Irish man at the centre of family and nation. Conrad identifies a pattern whereby family members hide transgressions in Irish families from the eyes of potentially disciplinary institutions ( $p$. 9). The family cell in Ireland regulated itself then, according to Conrad, by keeping to itself and thereby keeping its instability out of view. This self-preservation drive within the family, in Conrad's view, promotes the interests of both the nation-state and capitalism.

Alongside her thesis that the family cell functions to maintain the heteronormative national status quo, the argument is also advanced that family can act as a site of resistance when it enables self-preservation and self-reliance in the face of colonization. The main aim of this book, however, is to show how private sexual relations and the operation of 